DE DE GRUYTER

OPEN

Polish Cartographical Review

Vol. 47, 2015, no. 2, pp. 77-90

DOI: $10.1515 /$ pcr-2015-0009

BEATA KONOPSKA

Institute of Geodesy and Cartography, Warsaw

beata.konopska@o2.pl

JACEK PASŁAWSKI

Department of Geoinformatics, Cartography and Remote Sensing

University of Warsaw

jpaslaws@uw.edu.pl

\title{
Polish adaptation of foreign geographical atlases for general use at the turn of the 20th and 21st centuries
}

\begin{abstract}
Different approaches to the adaptation of foreign geographical atlases, making an effort of classification, against a background of the intensive activity of Polish publishers in the scope of adaptation of these atlases during the last decade of the twentieth century and the first decade of the twenty first century have been discussed in this article. Moreover the usefulness and correctness of the adapted publications as well as the fundamental problems connected with the use of Polish geographical names have been discussed from the point of view of a Polish user; also the problems related to the layout, range of content and scope of symbolism expected by a Polish user have been discussed.
\end{abstract}

Keywords: geographical atlas, copyright license, adaptation of atlases, geographical names

\section{Introduction}

An ambition of a publisher with the significant and established position on the book market is having on an offer the general geographical or historical atlas of the world. "Traditionally, and now, I think, not so much has changed - Władysław Pawlak wrote in 1999 - there was an opinion that the geographical or historical atlas is the last position, in which a publishing house, stable from the point of view of staff and finance, is interested". Seen from one side from the point of view of high substantive demands, which are set for a publisher to develop the general geographic atlas, from the other side - from the point of view of capital-absorption-editorial-printing process, this opinion is current for today, like years ago. A large volume of such a type of publication, substantively and technologically complex mapping procedure require from a publisher to finance a team consisted of a dozen or so, or a few dozen of authors experts in the field of knowledge and experienced editors cartographers.

This opinion, however, concerns only the case in which an initiator, organizer of the publishing process and a copyright owner is one publisher.
A characteristic feature of the publication, which came into existence in such a way, is usually a long time of its functioning on the market, often counted in an impressive number of the several dozen and sometimes even more than a hundred editions, as in the case of the German school Diercke Weltatlas (150 editions) or the historical atlas of the world by Putzger (104 editions). It is possible to assert that the atlases of an extensive content and of a good standard of printing from the renowned publishing houses function like the encyclopaedias and dictionaries. The circumstances, which favoured the publishers after the year 1989, encouraging them to take the decisions about engaging in the adaptation of foreign works, and impeded them from taking an effort to develop their own, were very interesting. In this connection, a question arises: to what extent there was an impact of the external, macroeconomic conditions and the socio-political climate on such decisions, and to what - the internal factors, such as the development strategy of a publishing house, its financial position, ambitions and merit or printing possibilities of the publishers? It can also be important to reflect on functioning of an adaptation in the 
social terms, taking into account the transfer of other cartographical traditions to the Polish environment. The practice of publishing proves that the broad complements of geographical and historical atlases can also be achieved by adapting the works of other publishers without having to create a team of authors, engaging the experts and incurring the financial risk that is associated with the development of own publishing house.

An adaptation of a work is the consequence that comes from the consent of a copyright owner given to another publisher to make the certain changes in the work and release it within the stipulated time and edition as well as to distribute on a particular territory. A licensed or official (Terms and Conditions) authorization allows a new publisher to use the entire work or any part thereof to customize them to suit the needs of the publisher complied with the local habits of readers and market conditions.

"Adaptation" is a word derived from the Latin adaptatio - "adjustment"; according to the Nowy Słownik Języka Polskiego PWN (New Polish Language Dictionary PWN, 2000) it is the action or process of adapting of something connected with the implementation of the necessary changes to perform the new functions. The word "adaptation" is defined similarly by Encyklopedia PWN (PWN Encyclopedia): it is a transformation of a literary work into a different kind of literary work or into other work of art, adapting it to the needs of new users or new means of distribution ${ }^{1}$. On the other hand, according to the Law of February 4, 1994 on copyright and related rights, an elaboration of another person's work, in particular translation, alteration or adaptation, is copyrighted without a prejudice to the original work (Dziennik Ustaw 1994).

\section{Adaptation of general geographic atlases in Poland after 1989}

\subsection{Subject-matter and purpose of the study}

The general geographic atlases adapted to the Polish users at the turn of the 20th and 21 st centuries are the subject-matters of this

\footnotetext{
${ }^{1}$ http://encyklopedia.pwn.pl/haslo/adaptacja;3865734. html; entry15.07.2015.
}

study. The lower dividing line was set by the year 1989 , conventionally accepted as the beginning of the Polish transformation ${ }^{2}$, for the upper one the year 2011 was adopted, when the "Polish Cartographical Review" stopped the registration of published maps and atlases, remaining only in the cartographic literature.

The main objective of the research boils down to determine a degree of the adjustment of foreign publications to the needs of a Polish reader in the context of the practical knowledge of cartographer. When in this way the problem is formulated, two groups of specific issues appear: the first one strictly relates to the cartographic principles, the second one associates with the external environment and has a supplementary character.

From the point of view of the cartographic principles it is interesting to determine which the elements of atlas and map content are absolutely changed to adapt to a Polish user, to which extent the structure of an atlas is modified and to which - the content of the maps is changed. It is also interesting to identify the substantive issues, which were encountered by cartographers, and which facing mistakes we failed to protect.

\subsection{Sources and research methodology}

Formulating the purpose of the research, it was indicated that the subject matters of the research were the adaptations of general geographic atlases published in Poland after 1989, so the source was adopted as the basis for all the atlases registered in the section Editorial News, Maps and Atlases of the "Polish Cartographical Review" between 1989 and 2011. On the basis of the lists, which were published in the journal, 62 atlases were registered as the adaptations of foreign publications, while

\footnotetext{
${ }^{2}$ After the conventional date of the 4th of June, 1989 , when the Parliamentary Elections had been held in Poland, the new economic system began. A package of important laws laid the foundations of publishing activity. The first law, that gave the freedom of economic activity, had been implemented at the end of December, 1988 (Dziennik Ustaw 1988, no. 41, unit 324); the second law, which liquidation the preventive censorship, i.e., the repeal of the Act on the Control of Publications and Performances, the abolition of the Inspection Bodies of the Control and the changing of the mentioned Act, called the Press Law, was put in force in April, 1990 (Dziennik Ustaw 1990, no. 29, unit 173).
} 
2 publications were elaborated in Poland in accordance with foreign editorial guidelines. Mostly, they were the overall general information atlases, both for general use and for young people because there were about 50 of such the atlases. A separate group, that is not the subject for analysis, consisted of 9 thematic atlases (among which the most numerous group consisted of the adaptations of road atlases of Austrian and German publishers), 2 satellite atlases and 2 atlases presented the migration of birds, e.g. ornithological atlases. Another separate group was formed by the adaptation of 14 historical atlases. It could be expected, that a number of the adaptations of atlases was slightly larger, but those adaptations were rather ephemeris for some little editions.

Reviewing the literature on the subject, it was noticed, that the issue of adaptation of foreign geographical atlases was taken mainly in the form of reviews, sometimes quite extensive, the authors of which drew the attention to various aspects of that kind of publishing. Those reviews were mostly published on the pages of the "Polish Cartographical Review", but, although less frequently, also in other journals, e.g. in "Geografia w szkole" ("Geography in School"). In principle, there no wider study on that topic appeared, although there was one noteworthy Master thesis, which has never been published, written under the supervision of dr. Bogdan Horodyski at the Chair of Cartography, University of Warsaw, in which 12 adaptations of selected atlases both for schools and general use as well as one atlas for the kids ones had been discussed (T. Figurski 2005).

Due to the type of the source material gathered and the problem taken, the analysis of the document was selected as the main research method. The results should allow for achieving a goal by formulating the answers to the specific research questions.

\subsection{Analysis of atlases}

The new situation, which occurred in Poland after 1989, favoured a free circulation of copyright and a process of adaptation of foreign publications for the Polish audience. Although initially it was a time of total failure of the economy and still there was practically only one cartographic publishing house called Państwowe
Przedsiębiorstwo Wydawnictw Kartograficznych (PPWK), which for almost forty years had been meeting the needs of the user in the scope of mapping for educational aids and maps for general use: general geographic, auto and tourist maps, etc., but the shortage of maps and atlases on the market was still a reality; although the liquidation of censorship and the abolition of centralized management of publishing houses began to conduce to the emergence of new publishing houses. Those publishing houses without the substantive facilities began to reach for the foreign studies in order to adapt them to the Polish market.

At that very time in Western Europe a new direction of the elaborations of geographic atlases had been developing. The atlases for general use, enriched with descriptions, explanations, photos and drawings, appeared. The lack of such publications on the Polish market was clearly noticeable.

Thus, the decision to introduce the Polish translations of such publications, primarily Western, into the market was certainly enriching it, though some cartographers assessed "the novelties" with scepticism. We could cite here the reflection of B. Horodyski (2008, p. 65) from one of the reviews: "l'd like to know, whether this need (this type of publication) follows from imperfection of the maps in themselves or, maybe, from the difficulties of their interpretations by poorly educated users".

\subsubsection{General information atlases}

An example of one of the extensive atlases adapted for the Polish market is the Atlas encyklopedyczny PWN (PWN Encyclopedic Atlas) released in 1998; it is an adaptation of Grande Atlante Geografico of the recognized De Agostini Geographic Institute in Novara (fig. 1). Scientific Publishing House (PWN) encouraged the holders of the six-volume Nowa encyklopedia powszechna (New Universal Encyclopedia), the edition of which was coming to finish just in the last year of the past century, to acquire the Atlas by issuing it in the cover graphically referring to the volumes of the encyclopedia, but not referring to the already published volumes in the scope of format. This atlas contains an extensive introducing section (text, photos, drawings), comprising $1 / 3$ of the total volume. Maps at the basic scale of $1: 3,000,000$ consti- 


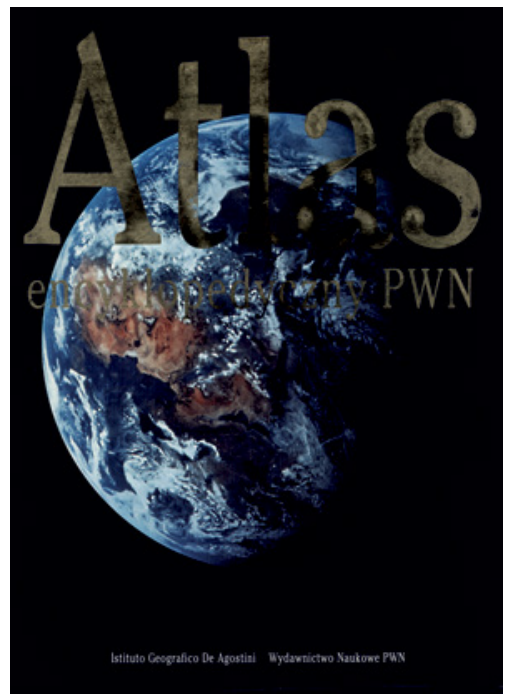

Fig. 1. Polish adaptation of Italian geographical atlas Grande atlante geografico De Agostini

tute $40 \%$ of this atlas. Poland can be found on the tenth map entitled Europe - the Central Part at the mentioned map scale. Maps of the Atlas are followed by the seven pages of the section "Maps of the Parts of Poland". It includes a two-part map of Poland at the scale of $1: 1,500,000$ from the national Atlas Rzeczypospolitej Polskiej (Atlas of the Republic of Poland), two maps Surface Relief and Communication and Administrative Division (1:3,000,000), four climate maps $(1: 7,500,000)$ and at the last page - the map of Warsaw $(1: 120,000)$. This part is clearly different from the whole atlas, both thematically (the atlas does not include the climate maps) and graphically.

This difference is emphasized by the detailed indexes: Index of names - Polish part and Index of names - a map of Warsaw (J. Korycka-Skorupa, T. Nowacki 1998). Neither in the encyclopedic volumes published during the years 1995-1999, nor in its supplement it does even mention about the existence of this atlas. It is therefore an encyclopedic atlas in its name only.

In 1993 there was Wielki ilustrowany atlas świata (Great Illustrated Atlas of the World) released, which contained 47 two-paged text descriptions for selected issues, for example, "The time saved in layers", "The driest lands",
"Secrets of the deep", "Cosmic forces". Signed by the publisher GeoCentre Warsaw, de facto it was prepared by Reise- und Verkehrsverlag. Following this direction PPWK published two years later, in 1995, its own Świat. Atlas geograficzny z częścią encyklopedyczną (World. Geographical Atlas with encyclopedic part) using, inter alia, the maps from two-volume Geograficzny atlas świata (Geographical World Atlas) published in 1987 and 1989.

Atlases of GeoCenter also brought another novelty to the Polish users. Those were the atlases containing maps from all over the world at the scale of 1:4,500,000 and at larger scale of $1: 4,000,000$. The presentation of the whole world at a uniform scale was carried out in a series of German Atlases, which have been translated into many languages, including also Polish. It was the monumental Księga świata (Book of the World) $(1: 4,000,000)$ and the Nowy atlas świata (New Atlas of the World) of a significantly smaller volume (both atlases were released in 1996). Those atlases included a new type of maps. The suggestive colours of nine "continental ecological zones" were imposed on the shaded relief of the terrain to give a rather interesting effect.

The content of the maps was also a rich settlement, road network with a mileage rate, railway network and the designation of different places worth visiting. According to the reviewers, those maps marked a breakthrough concept of universal general geographical atlases of the world (W. Ostrowski, M. Pizoń 1998).

The striving for an attractive form, typical for that time, could be clearly seen in the publications targeting a wide audience, both schoolchildren and adults interested in the world, which opened up against the Poles at that time. We could mention here the adaptations of the popular atlases of London publisher Dorling Kindersley that were issued by Polish Publishing House "BGW", which had no cartographic traditions at all, under the titles Ilustrowany atlas świata (Illustrated Atlas of the World), and the Atlas świata (Atlas of the World). The keeping of original layout of the maps by the Polish publisher caused, that the maps were given as an example of an unusual for us succession of the continents. On the first of the continents the map part was opened by the Polar regions, followed by the maps of Canada, the United States of America and South Ame- 
rica. In the Atlas świata, which was doubly vaster, the first maps were the maps of North America, the next ones concerned the Europe, and the last map showed New Zealand. There were no maps of Polar regions! It could be assumed, that the readers fascinated by the interesting illustrations and text around the maps did not notice that unusual arrangement. They would rather pay an attention to Poland. And that was placed on the map "Central and Eastern Europe" together with such countries as Czechoslovakia, Yugoslavia, Hungary, Romania and Greece (pp. 50-51), whereas in the second, vaster atlas, Poland was placed already with the Czech Republic, Slovakia and Hungary (pp. 70-71).

\subsubsection{School atlases}

Within the school geographical atlases our attention was grabbed by the adaptation of Alexander Schulatlas elaborated in 1993 by Ernst Klett Schulbuchverlag in Stuttgart, prepared for the Polish schools by two former monopolists: School and Pedagogical Publishing House (WSiP) - in the range of school books, and Polish Cartographical Publishing House (PPWK) - in the range of cartographical teaching aids. That atlas appeared in 1998 entitled Szkolny atlas geograficzny (School Geographical Atlas, fig. 2) and in fact was adjusted to our school program. From a substantive point of view the atlas introduced some kind of novelty in teaching. Its first release in German Federal Republic in 1976 became an event, because the authors nearly completely broke off with the common geographical map of a hypsometrical type for the new, at that time, landscape maps. Considering the experiences of our schools, the atlas from 1993, which consisted again of hypsometrical maps of the continents, was accepted for an adaptation. The part dedicated for Germany was substituted with 36 maps of Poland, which was $15 \%$ of the maps of that atlas and - from the point of view of reviewers - the geographical names were earnestly elaborated. To simplify the usage of that atlas, the methodological guide appeared, developed by W. Kaiser in 1998, an employee of WSiP. A significant defect of that atlas was its weight $1.5 \mathrm{~kg}$, a considerable weight as for an atlas carried in a briefcase of a young student. It was expected at that time that it would be an aid used in a geographic classroom only (J. Angiel 1998, J. Pasławski 1999).

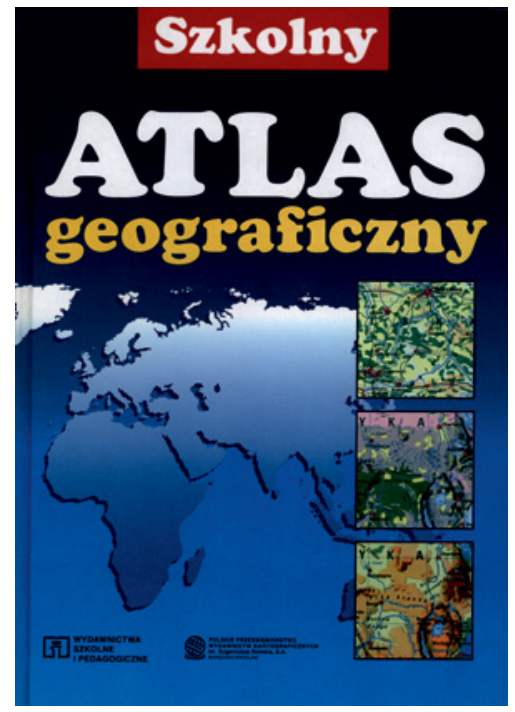

Fig. 2. Polish adaptation of German school atlas Alexander Schulatlas

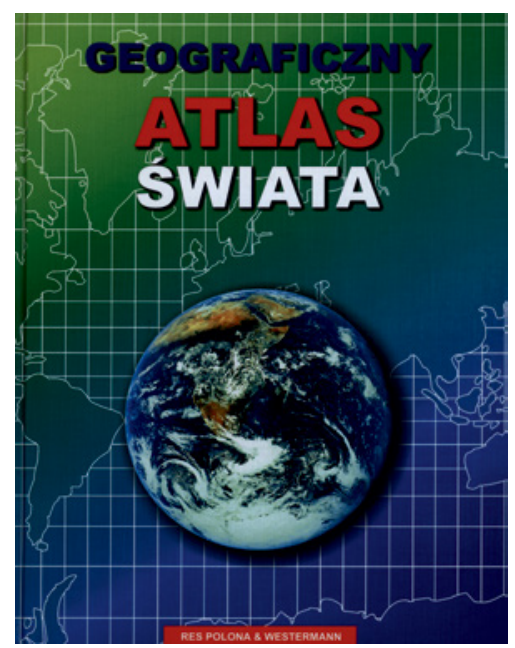

Fig. 3. Polish adaptation of German school atlas Diercke Weltatlas

During the analysis of the content of Szkolny atlas geograficzny our attention at the first glance was paid to the graphics of the general maps of Poland, because such a type of graphics was an alien one for the Polish tradition (J. Pasławski 1999). However it was not just a case of aesthetics. Browsing the atlas, we 
could notice, that the east frame on the maps of Europe extended from Arkhangelsk across Moscow to Istanbul. Outside Europe is not only Ural, but also West Ukraine with Donbas. On many thematic maps the geographic grid was missing. The relief of the bottom of oceans was only shown on the map World. The Relief of the Surface (pp. 124-127). The legends of hypsometric maps were not adapted to our maps: that very fact did not help to imagine the relations of heights. And yet, those maps formed our imagination, attitudes and views of our pupils. Judging those kinds of publications, we needed to remember it as well. Later, in 2001, Geograficzny atlas świata (Geographical Atlas of the World) showed out (fig. 3), prepared by the raised in 1989 Polish Educational Publisher Res Polona in cooperation with the existing from the 19th century German Publishing House Westermann (J. Ostrowski 2002). That Atlas was an adaptation of the school atlas with among 100 years of tradition, i.e. Diercke Weltatlas from 1988. Editor of that adaptation, W. Pawlak, made the efforts to adapt the atlas for the Polish pupils, because, although, it was not shown in the title, it was in fact an atlas designed for schools. A section consisted of 15 pages dedicated to Poland was introduced, as well as a very carefully developed geographical names. It is necessary to mention, that the adaptation of new maps to the style of the whole atlas is worth the attention. Each map was signed by the publisher, so that you could indicate the elaborations of the Polish authors, which did not deviate from the point of view of graphical style from maps in the Diercke's atlas.

Since the early nineties, a dozen of geographical atlases had appeared, and not only the adaptations bearing in their titles the phrase "school", but completely unsuitable for the school use. Let Szkolny atlas świata edited by Arkona Publishing House in 1992, being an adaptation of The Children World Atlas issued by the closer unknown English llex Publishers in Oxford, would be an example. The maps were developed ignoring the neighbourhood countries and continents ("Inselkarten"). They were lack of geographic grid, because as we read in the introduction, "In order to achieve greater legibility of the maps, the meridians and parallels had been omitted"! A bizarre idea of the authors of English original was shading the map of the world in interrupted projection after Goode (p. 8), so that the map looked like three spherical surfaces (fig. 4)! The map of Poland was at the 31 st page, and the only adaptive tooling were the Polish geographical names, often mistakenly placed (J. Pasławski 1993). More similar atlases, just absolutely not suitable for the needs of the schools, appeared in the analysed period.

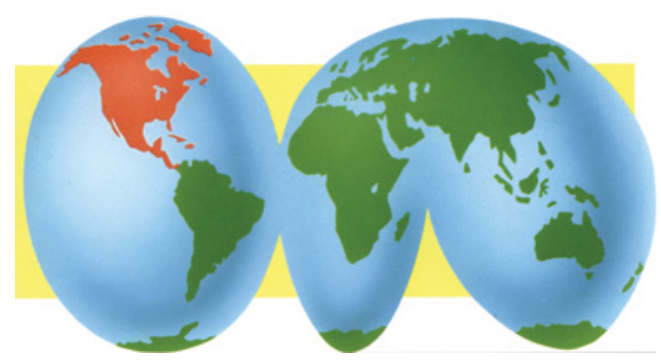

Fig. 4. The shaded segments of the world map in the interrupted projection by Mollweide from the Szkolny atlas świata (School Atlas of the World) edited by the Arkona Publishing House

\subsubsection{Pocket atlases}

The third group of atlases, which found their way into our market, was a group of pocket atlases. That kind of atlases, as we have already mentioned before, PPWK had issued since the beginning of the sixties, however, in the early years of economic transformation, the publishers decided that such handheld small atlases would find their buyers. It is interesting, that the originals of such two adaptations, which appeared in 1991 and 1992, were the Soviet atlases issued in Moscow: Geografičeskij atłas mira (Geographical Atlas of the World) (GUGiK 1989) and Atłas mira (World Atlas) (Kartografija 1988), the original of which was the pocket atlas previously known in Poland as Attas mira from 1988.

The first of those atlases mentioned above, Geograficzny mini atlas świata (Geographical Mini-Atlas of the World), had been released in early 1990 , so the talks about its publishing and printing had to take place in the Soviet Union before the suppression of censorship in Poland. In the context of a publisher the decision to issue a circulation of 100 thousand copies (and the resumption of the same edition next year) may be astonished, because the 
atlas was very modest, counting - according to T. Figurski (2005) - only 4 thousands geographical names. In turn, the release of the second one of the said atlases with the Polish title Kieszonkowy atlas świata lat dziewięćdziesiątych (The Pocket World Atlas of the Nineties) in 1992 by the Foundation for Innovation was definitely unfortunate decision in the light of J. Ostrowski's review (1993, p. 137) - "... an atlas adapted in Moscow for the Polish contractor without an adequate professional control from our hand is a hotbed of an improbable number of several hundred different kinds of errors, inconsistencies and omissions, the list of which yields very little in terms of volume to the whole atlas!".

\section{Results of the research}

The analysis of the collected material shows the differences in the approaches of the publishers to adaptation, although some similarities in their activities can be noticed. Some relationships emerged between the scope of changes introduced to an original work and the profile of a publishing house, especially its early experience in the field of cartography and market position. In any case, regardless of the type of atlas, we are dealing with the translation of a text layer into Polish, i.e. geographical names, explanations in legends and descriptions, sometimes quite extensive.

\subsection{Geographical names}

An issue connected with the introduction of Polish geographical names, which is quite often identified with the adaptation of foreign atlases, is a very vexed question. Judging by the results, we do not always undertake the adaptation being aware of its complexity. A situation, when a Polish publisher decides to implement the Polish geographical names and to translate the text, should be called the translation of the atlas. An elaboration of new maps for the needs of atlas and deleting the maps, which are unnecessary for the Polish edition, is already the adaptation, in our opinion. From the perspective of an editor - translator, we can divide the geographical names into several groups.

It is relatively easy to use the geographical names from the areas of the Latin alphabet, when the names, which do not differ in a form of writing from the local (original) names, are put on the maps, e.g. Oslo, Berlin, Boston, São Paulo. Using the foreign maps, you need to know which of these names have Polish exonyms, e.g. Brunszwik (Brunswick), Padwa (Padua), Bolonia (Bologna). Fairly frequent errors in the scope of geographical names might result from the lack of relevant data. In the early nineties the Polskie nazewnictwo geograficzne świata (Polish Geographical Names of the World) by L. Ratajski, J. Szewczyk and P. Zwoliński (1959) had been used yet, and particularly embarrassing was the situation created after the breakup of the Soviet Union in 1991, which could be the source of errors, because the official language of geographical names, language, which had been in force until the former Soviet republics became the independent states with their own languages and alphabets, was Russian.

It should be recalled, that for two years (in the years 1994-1996), so during the first decade of publications of the discussed atlases, the Commission on Standardization of the Geographical Names Outside the Country at the Ministry of Education had been developing and the Surveyor General of Poland had published an elaboration titled Polskie nazewnictwo geograficzne świata (Polish Geographical Names of the World, about 6,400 names), then, in the years 2004-2010, the Head Office of Geodesy and Cartography had been releasing Nazewnictwo geograficzne świata (Geographical Names of the World, 12 parts) developed by the Commission on Standardization of Geographical Names Outside the Republic of Poland affiliated to the Surveyor General of Poland, and in 2013. Urzędowy wykaz polskich nazw geograficznych świata (Official List of Polish Geographical Names), developed by that Commission, containing 13,358 Polish names of geographical objects, appeared (M. Zych 2014). In the case of geographical names used in the languages which, in their turn, do not use the Latin alphabet, it is necessary to use the publications elaborated by the Commission, because these are the issues, which constitute a real linguistic jungle.

While adapting a foreign atlas, the main problem, however, comes down to the selection of the names on the its particular maps, which have Polish exonyms, and then, to the repla- 
cement of the original names by these exonyms (or to the addition them to the latter ones). We meet here with different approaches and degrees of such adaptation, which were compiled and characterized by T. Figurski (2005). Looking through the above-described examples of different types of atlases, it is necessary to note the difference in interpretation of the names of natural objects (mainly oronyms and hydronyms) and political units (countries, states, etc.), and a distinct, different approach to the place names. These primaries, when we have settled their Polish counterparts, are translated and presented basically only in Polish. In the case of a locality we affirm, however, either only the replacement of the original names by exonyms, the examples of which are Geograficzny mini atlas świata edited by the Wiedza Powszechna Publishing House and both of the atlases of the Polish Publishing House "BGW", or putting the Polish names in first and then, bellow them, in brackets - the original names, e.g. in the adaptations of both the German school atlases or vice versa - the replacement of the original names by Polish exonyms, e.g. in the Nowy atlas swiata (New Atlas of the World) edited by GeoCenter.

However, in most of the analysed atlases the use of the above adapted options of naming is fraught with the numerous derogations and even glaring inconsistencies or ordinary mistakes. For example, in Atlas encyklopedyczny $P W N$ from 1998 on the map called Europe Central Part the names are Polonized, but, unfortunately, it is done in a very inconsistent way. They are the names of the larger bodies of water and forms of the bottom relief. A very strange rule of inserting the Polish exonyms only inside the area of the title continent is realized. So, Polish exonyms: Jerozolima and Bagdad are not placed on the map of Africa, but you can find these exonyms on the map of Asia only. Moreover, they are Polonized partly. The names of Norymberga (Nuremberg) Brema (Bremen), Wiedeń (Vienna) are Polonized, but, the names of Kiel and Speyer, among others, are not.

Other inconsistencies are noted in two atlases adapted by the Publishing House GeoCenter. The first one is Wielki ilustrowany atlas świata (Great Illustrated World Atlas, 1993), which is an unique example of the inconsistency in adapting the original geographical names to the needs of a Polish user. Due to the limitation of a number of Polonized names by the German publisher, Polish editors left the numerous names in its original forms, despite the widespread use of their exonyms. Among the mountain ranges the Vosges Mountains (Wogezy), the Sumava (Szumawa) and the Rhodope (Rodopy) were translated into Polish, but Ardenas, Erzgebirge, Alpi Transilvaniei were left in their original forms; among the islands, such names as Illes Baleares, Corse and Prince Edward Island retained their original forms, as well as the rivers $\mathrm{Po}$, Seine and Rhein or the lakes Bodensee, Lasožskoje ozero and Lake Victoria, which were also left in their original writing form. In turn, in the Nowy atlas śwata (New Atlas of the World, 1996), apart from the similar omissions of the Polish names of islands, rivers, lakes, etc., was also a lack of such important exonyms, as Budapeszt (Budapest), Drezno (Dresden), Madryt (Madrid), Stambuł (Istanbul), Szanghaj (Shanghai) or Tokio (Tokyo), despite the adoption of the principle of refilling their original names by exonyms.

In other atlases various kinds of inconsistencies and mistakes are not so numerous, no less a few are worth quoting. So, in an otherwise very correctly elaborated Szkolny atlas geograficzny (School Geographical Atlas), adopted by WSiP and PPWK the original names, among others, London (Londyn), Brest (Brześć), Riga (Ryga) and Jerusalem (Jerozolima) are not placed under the exonyms and left only the original name of Morawský Kras, but in the Ilustrowany atlas świata (Illustrated Atlas of the World) by Polish Publishing House "BGW", in which only the Polish exonyms are used Zürich (Zurych) was overlooked.

\subsection{Draft content}

Someone, who is taking the new atlases for an adaptation should carefully countercheck the contents of all the maps. For example, as for the classification of the towns and its validity, place, in which the signatures are located in relation to the rivers, and corectness of the state borders are concerned, they are very challenging. It is relatively easy to locate the name of the city in a proper place, but it is technically harder to locate its signature in a right place, e.g. in relation to the coastal line. The 


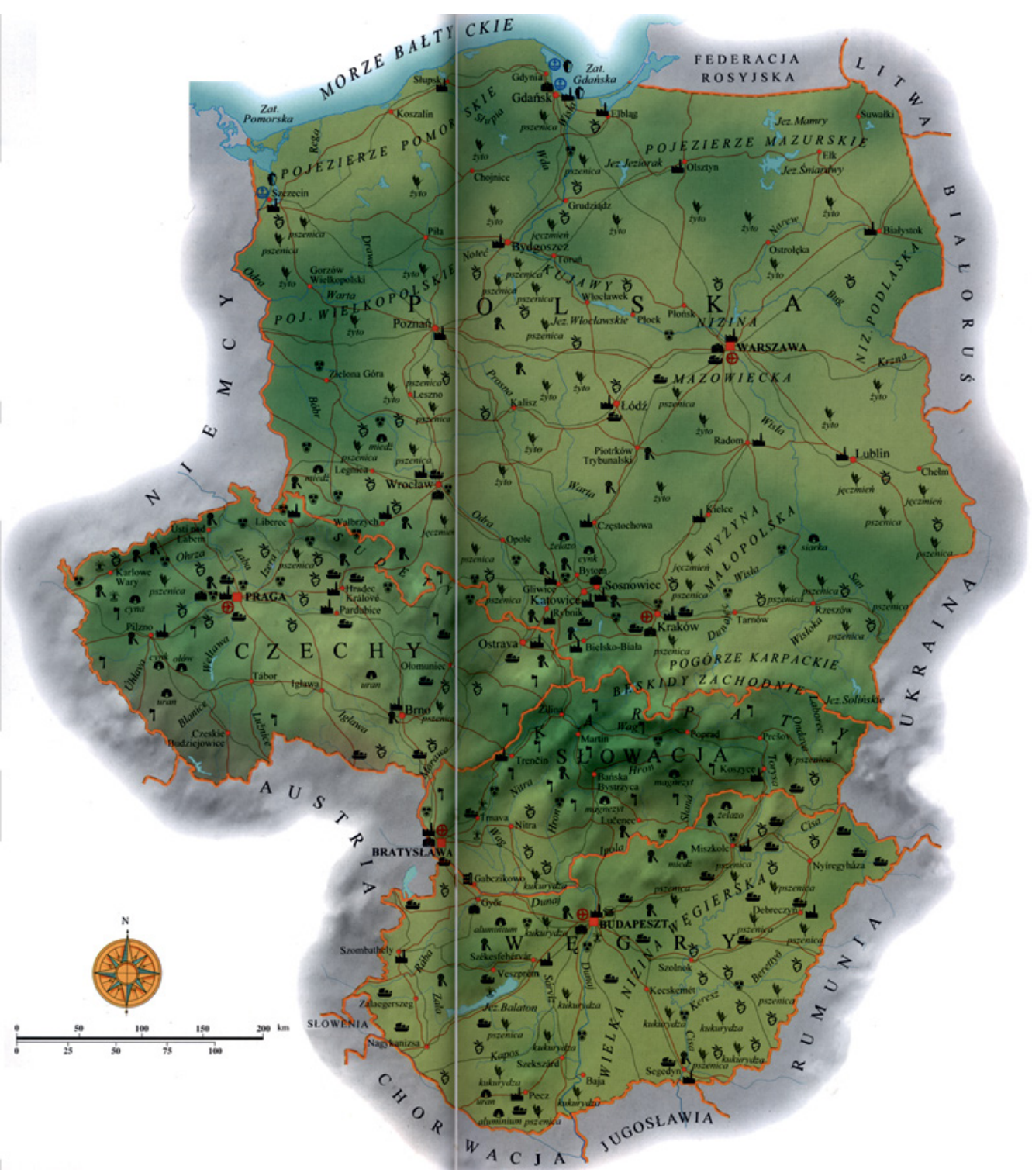

Fig. 5.The map "Central Europe" at the scale of 1:3,000,000 from the Atlas świata (World Atlas) of Polish Publishing House "BGW"

litmus paper of cartographical solidity of the authors and editors of foreign atlases is checking the content of the maps presenting Poland.

Kieszonkowy atlas świata lat dziewięćdziesiątych (Pocket World Atlas of the Nineties) from 1992, where, e.g. on the maps of the countries located in Central Europe (pp. 6-7), the Hel Peninsula has $8 \mathrm{~km}$ of width at the top and then it narrows (instead of expanding) to the bottom, and the island Wolin is divided from the mainland not by a strait, but by the river Dziwna, is showing us many examples of 


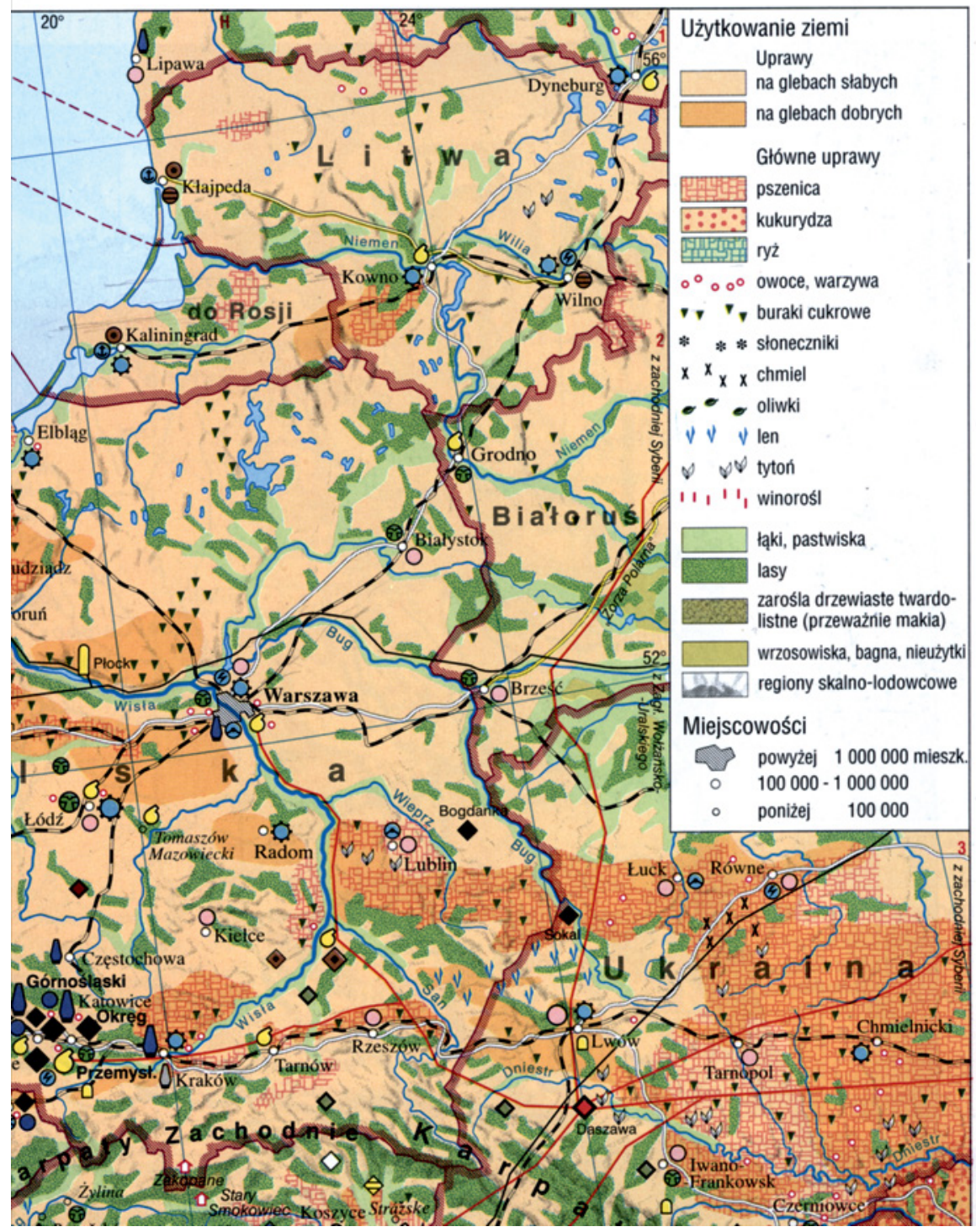

Fig. 6. The eastern Poland on the economic map of Western and Central Europe from the Geograficzny atlas świata (Geographical World Atlas) by Res Polona

various derogations in the image of the lands of Poland, which have been already criticized above. In the same atlas, on the map of Poland (pp. 8-9) the coastal lakes Jamno and Bukowno are shown as the bays of Baltic Sea, Elbląski and Augustowski Canals - as the rivers, but the meaningful cities like Bełchatów, Lubin or Zgorzelec are ignored, despite considering the several villages.
Equally surprising derogations can be seen in the presentation of the Polish water networks on the map "Central Europe" (pp. 70-71) in the Atlas swiata (Atlas of the World) of Polish Publishing House "BGW" (1995). Vistula flows here from the Lake Goczałowickie (!), Noteć from the Lake Pakoskie, the upper section of Warta is the river Liswarta, which flows from Woźniki, and island Wolin is separated from 
Uznam not by a strait, but by the river Świna (fig. 5).

Some stumbles, but mainly intermittent, also happen to the authors of prestigious school atlases, example of which is an economic map of Western and Central Europe (pp. 46-47) in Atlas geograficzny świata (Geographical Atlas of the World) published by Res Polona, with the repeated after Westerman, an incorrect course of the north-eastern border of Poland and railway Warsaw - Bialystok (fig. 6).

As the practice has shown, the mistakes of this kind and derogations in the content of the maps (we can also find them on the map of the areas from outside Poland, e.g. the outdated coastal line of the Aral Lake) are reproduced in the Polish atlases, because they are hard to delete.

\subsection{Types of adaptation}

The analysis of the selected materials allowed us to try to group the adaptations considering the range of the changes made by a Polish publisher, in the context of his/her earlier experiences and substantive and financial capabilities. Depends on capabilities of publisher, degree of workload, and finances, we can set apart some attitudes to the adaptation of atlas.

With a particular case we have to work, when a foreign publisher, working on an international market, commissions the cartographic institutions or personally cartographers from the countries, where he has his representative offices, an elaboration of atlas or so called a regional part for the world atlases according to his assumptions. It usually has some connections with the wider, often international publishing series. An example is the worldwide activity of Reader's Digest Publishing House. It began its activity in Poland in 1995, publishing its books in the several branches: dictionaries, fiction, cook books and atlases. For the order of this publisher the Cartographic Laboratory of the Institute of Geography and Spatial Organization at the Polish Academy of Sciences elaborated two road atlases and Ilustrowany atlas Polski (Illustrated Atlas of Poland). This atlas of almost 300 pages has been developed in accordance with the assumptions of the contractor. Reviewing the atlas, B. Horodyski (2008, p. 65) wrote: "A whole is professional, but also popular, clear and interesting", and moreover, "The whole atlas has been carefully reviewed and beautifully printed, what a pity, that in Belgium." This is not a situation, which we can define as an adaptation. This is more of an accomplishment of an atlas according to "outer" assumptions. The experienced editors know, that the final effect can be the similar, but also very different from the previous traditions of the local cartography, and that is why we list it in our description.

A special case is when a Polish publisher acquires the rights to the individual maps or a part of the whole work and develop the atlas in accordance with his own concept. The resulting work is therefore the entirely new original publication in structure, but compiled with own maps and maps that are the adaptations. The atlases of the Demart Publishing House from Warsaw, Poland, are very good examples, because, as it seems, the Hungarian company Cartographia has left the Polish publisher the freedom to use its materials. Demart since the mid-nineties has regularly cooperated with the Hungarian publisher in adapting its atlases for the Polish readers. A school atlas based on Hungarian materials, but with quite a large participation of own Polish maps, elaborated in the system proposed by the contractor, was the beginning. Then, using the similar principles, there were common atlases for general use elaborated in different atlases. Two of them were reviewed in our quarterly. J. Ostrowski (2006a,b) by comparing Wielki atlas świata (Great Atlas of the World) with a Hungarian atlas that was its foundation wrote with an appreciation:"...leafing through the lying side by side two atlases - Hungarian and Polish adaptation of the original, once we see the significant differences testifying about a large contribution of the team of Demart. This applies to both the structure of the whole and the certain elements of the content and graphics of maps (2006a, p. 165). But it difficult not to mention a certain minus of bringing into use the customs of Hungarian cartography to Polish market. Well, in school atlases the horizontal, diagonal projection of the world map, elaborated by Baranyi, appeared, and never explained. Yet F. Uhorczak so stubbornly promoted the projection of Mollweide in Polish cartography!

Moreover it is possible to offer two basic types of adaptation: basic and complex

Basic adaptation. Together with the phenomenon of globalization, publishers operating 
on the international market developed. They focused on the elaboration of universal concept of an atlas, usually the atlas of the world, and on customizing the technology of its performance to the simultaneous printing in some independent language versions. Such a solution has facilitated the dissemination of modern printing processes, which allow printing the maps in four colours as a basis for all language versions, but without the language layer (geographical names and other texts). The language layer was overprinting as the fifth one in the edition dependent on a person concerned. This type of organization of production minimized its costs in a unique way. First of all it was dealing with the atlases richly illustrated and published on a high level of printing, much higher than it was available in Poland in the last decade of the 20th century. For Polish readers the publications of such a kind were at that time the synonyms of luxury. Not a high substantive value of these publications, trivial comments and other considerable shortcomings of the content were marginalized in the light of qualitatively great paper, accurate print, excellent colours and rarely seen in Polish publications good reproduced photos. The popularity of this kind of adaptations after the Polish transformation was the greatest.

So, then it is the only preparation of the Polish text layer, in the other words, it is the translation of the publications into Polish, without any opportunity to interfere into the structure of a work and a greater possibility of correcting the factual errors. Such a kind of adaptations, or basically translations, are carried out by different publishers, not necessarily dealing with cartography, because it does not require the involvement of editors cartographers, but must be consulted with regard to the geographical names. The examples are the atlases discussed, elaborated by such publishers as GeoCenter and The Polish Publishing House "BGW".

Complex adaptation. In the case of world atlases, the traditional map succession in our atlases is: Poland, Europe, Asia and Africa, Americas (the both), Australia and the Polar regions. In the case of European publishing houses, most frequently we deal with German and English publications, in neither of the atlases the authors decide to change the order of the maps, their succeding, because such a change would pull out the significant costs.
The exception is the adaptation of Diercke atlas. The adaptation can rely on the replacement of the maps of a country, from where the original atlas has come from, with the maps of Poland, or on adding the additional pages with the maps of Poland. The Polish part has been included, of course, in both school atlases, while adapting Diercke and Alexander atlases, and in atlas of De Agostini Institute published by PWN as an encyclopedic atlas. The added map of Poland also appeared in the Kieszonkowy atlas świata lat dziewięćdziesiątych. That way the map of the Soviet Union, not existing in the moment of publishing the atlas, was replaced.

The complex adaptation includes the translation of the text layer and the introduction of a newly developed detailed part related to Poland. Very often the pages refered to Poland replace the sheets designed to demonstrate the country from which the original work is. The additional enriching parts of the thematic maps are happened to appear in this type of adaptation. Most often such an approach to the adaptations is presented by the publishing houses with the cartographic publishing profile or publishing houses employing the cartographers, stable from the point of view of financial position, with certain financial resource.

\section{Conclusion}

Referring to the adaptation of atlases for general use elaborated for the Polish readers and regarding to the undertaken research problem, it should be noted that the degree of adaptation of foreign publications is variable, and its scope is the result of negotiations between a publisher of the original atlas (the licensor) and a Polish publisher (licensee). Polish publishers having in their publishing profile the cartographic publications usually adapted the atlases according to a proposed, complex kind of publications, probably realizing to some extent their own publishing ambitions. Others, usually not affiliated with cartography, limited themselves to the translation of publications into Polish.

It should be clearly emphasized, that adapting the atlases in Poland after 1989 was not a new phenomenon, but it was fostered by many factors, especially the socio-economic transformation. The inflow of modern technological solutions to Poland, its entry into the global 
trading system of copyright turnover and statutorily ensured economic freedom have made that the adaptations of foreign publications on Polish market have become significantly easier and faster to implement than before. Adaptation, in the opinion of a young manager of a new, formed after 1989 publishing house was an effective action leading to a relatively fast and cheap supplement of publishing offer with a cartographical publication, compared with an undertaking the development of their own.

In turn, the same adaptation from the social point of view, is not unambiguous. It is no doubt, that some of these publications enriched many home libraries with valuable, new atlases, but there are quite frequent atlases containing wrong information, especially in the scope of geographical names. An attempt to introduce foreign geographical atlases for general use adapted to varying degrees had been checked by reading market.

Adaptations of foreign atlases, not foreign, because of their elaborations outside the country, but, primarily, graphically foreign towards our habits, often carrying a new vision of the world, different from our previous one, stored on the map, were generally accepted by our market. J. Angiel (1998, p. 314) interestingly presents his hesitations in the review of the Szkolny atlas geograficzny from 1998, an adaptation of German Alexander Schulatlas: “... a generation of geographers, who have been educated on Polish maps, may, however, regret something... Oh, even if these pure, beautiful colours on the general, geographic map of Poland (sorry, but I still cannot fall in love with German shaded maps, that appear 'pale' on one hand and 'dirty' on the other one)". In another review of the same atlas we can read, that "... there are many examples of foreign solutions for the Polish tradition and the teacher using the atlas should be aware of them" (J. Pasławski 1999, p. 129).

The market of school aids due to its size was an object of interests of many publishers, both newly created Polish and foreign ones, with long market history. Foreign publishers tried to enter the Polish market of school aids twice. Paradoxically, it was under the similar circumstances: i.e. the recovery of state independence by Poland, the first time after 1918, and the second time in 1989. The Austrian publisher Freytag und Berndt from Wien made a proposal to prof. E. Romer to persuade the Polish Publishing House Książnica Polska to adopt its atlases to the school market of interwar Poland and not to elaborate its own in turn, the Westermann tried to come into existence in the same market in the last decade of the twentieth century. In both cases, those activities ended without success. At the Conference "Geography of Poland on the threshold of the third millennium", which was held in autumn of 1999 , the authors of the paper about the achievements and state of Polish cartography posted: "A phenomenon, that worries some Polish cartographers, is an encroachment of foreign publications on the domestic market, that use a lacuna in the scope of modern, attractively issued maps and atlases. [...] In our opinion, the adaptations of good, foreign publications not only enriches the cartographic publishing market, but can also contribute to improving the quality of native cartography. Until then, the attractive external form, drawing the attention of a user, often creates a false pretence, behind which hides a low level of knowledge." (A. Czerny and all. 1999, p. 11).

In the nineties and the first decade of this century we saw quite a lot of activity of publishers in the scope of foreign publications. Currently, this activity has significantly decreased and the lack of even renewals would indicate a lack of interest in such a type of publications. Against the enormous political and economic changes, is clearly apparent a lack of current Polish home atlas at the appropriate level. Soon it will be already 50 years since the release of the most comprehensive and valuable Atlas świata (World Atlas) of Topographic Service of the Polish Armed Forces. 


\section{References}

Angiel J., 1998, (rev.) Szkolny atlas geograficzny. „Geografia w Szkole” R. 51, nr 5, pp. 313-315.

Czerny A., Kałamucki K., Ostrowski W., Żyszkowska W., 1999, Dorobek i stan polskiej kartografii geograficznej w ostatnim dziesięcioleciu. „Polski Przegl. Kartogr." T. 31, nr 1, pp. 3-14.

Dziennik Ustaw, 1994 nr 24 unit 83, art. 2, p. 1 (Journal of Laws).

Figurski T., 2005, Polskie opracowania zagranicznych atlasów geograficznych. Master thesis written under the supervision of $\mathrm{dr} \mathrm{B}$. Horodyski in the Chair of Cartography of the University of Warsaw.

Horodyski B., 1997, Zarys oceny merytorycznej kartograficznego ruchu wydawniczego w Polsce w latach 1990-1996. „Polski Przegl. Kartogr.” T. 29, nr 2, pp. 83-88.

Horodyski B., 2008,(rev.) Illustrowannyj atłas Rossii. Ilustrowany atlas Polski. Nasza ojczyzna. Mapy. Informacje. Krajobrazy. „Polski Przegl. Kartogr.” T. 40, nr 1, pp. 63-65.

Kaiser W., 1998, Jak pracować ze szkolnym Atlasem geograficznym. Przewodnik metodyczny. Warszawa: WSiP.

Korycka-Skorupa J., Nowacki T., 1998, (rev.) Atlas encyklopedyczny PWN. „Polski Przegl. Kartogr.” T. 30, nr 4, pp. 279-281.

Nazewnictwo geograficzne świata, 2004-2010. Warszawa: Główny Urząd Geodezji i Kartografii,

Nowy słownik języka polskiego PWN, t. 1 (A-Ó), 2000, Warszawa: Wydawn. Naukowe PWN.

Okonek M., 1994, (rev.) Przeglądowy atlas świata. Poglądowy $i$ zasobny $w$ informacje obraz Ziemi. „Polski Przegl. Kartogr.” T. 26, nr 4, pp. 230-232.

Okonek M., 1998, (rev.) Mały atlas świata. „Polski Przegl. Kartogr." T. 30, nr 3, pp. 202-203
Opach T., 2004, (rev.) Atlas świata „Polski Przegl. Kartogr.” T. 36, nr 3, pp. 211-213.

Ostrowski J., 1993, (rev.) Kieszonkowy atlas świata lat dziewięćdziesiątych. „Polski Przegl. Kartogr.” T. 25, nr 3, pp. 136-138.

Ostrowski J., 2006a, (rev.) Wielki atlas świata. „Polski Przegl. Kartogr.” T. 38, nr 2, pp. 163-166.

Ostrowski J., 2006b, (rev.) Świat w trzech wymiarach. Atlas ilustrowany. Mapy, fotografie, komentarze. "Polski Przegl. Kartogr." T. 38, nr 3, pp. 257-259.

Ostrowski W., 2002, (rev.), Geograficzny atlas świata. „Polski Przegl. Kartogr.” T. 34, nr 1, pp. 44-46.

Ostrowski W., Pizoń M.,1998 (rev.), Nowy atlas świata. „Polski Przegl. Kartogr.” T. 30, nr 2, pp. 124-128.

Pasławski J., 1993, (rev.) Szkolny atlas świata. „Polski Przegl. Kartogr.” T. 25, nr 3, pp. 135-136.

Pasławski J., 1999, (rev.) Szkolny atlas geograficzny. „Polski Przegl. Kartogr.” T. 31, nr 2, pp. 123-125.

Pawlak W., 1999, Kartografia w polskim systemie edukacyjnym. „Materiały Ogólnopolskich Konferencji Kartograficznych” T. 21, pp. 9-17.

Polskie nazwy geograficzne świata, 1994-1996. Państwowa Służba Geodezyjna i Kartograficzna. Warszawa: Główny Geodeta Kraju.

Ratajski L., Szewczyk J., Zwoliński P.,1959, Polskie nazewnictwo geograficzne świata. Warszawa: PWN.

Urzędowy wykaz nazw geograficznych świata, 2013. Warszawa: GUGiK.

Zych M., 2014, Nowy wykaz polskich nazw geograficznych świata i zasady jego opracowania na tle dotychczasowych publikacji. „Polski Przegl. Kartogr." T. 46, nr 2 pp. 140-161.

http://encyklopedia.pwn.pl/haslo/adaptacja;3865734. html; entry 15.07.2015. 